\title{
THE ROLE OF THE ALUMINUM SOURCE ON THE PHYSICOCHEMICAL PROPERTIES OF $\gamma$-AIOOH NANOPARTICLES
}

\author{
Rafael Romero Toledo ${ }^{1, *}$, Luis M. Anaya Esparza ${ }^{2}$, J. Merced Martínez Rosales ${ }^{1}$ \\ ${ }^{1}$ Department of Chemical Engineering, University of Guanajuato, \\ Noria Alta s/n. C.P. 36050, Guanajuato, Gto., México. \\ ${ }^{2}$ University of Guadalajara, University Center of Los Altos, \\ Av. Rafael Casillas Aceves No. 1200, C.P. 47620, Tepatitlán de Morelos, Jalisco, México \\ r.romerotoledo@ugto.mx
}

The effect on the physicochemical properties of aluminum salts on the synthesis of $\gamma$-AlOOH nanostructures has been investigated in detail using a hydrolysis-precipitation method. X-ray fluorescence (XRF), Fourier transform infrared spectroscopy (FTIR), X-ray powder diffraction (XRD), field-emission scanning electron microscopy (FESEM) and transmission electron microscopy (TEM), were used to characterize the synthesized samples. The specific surface area, pore size distribution and pore diameter of the different $\gamma$-AlOOH structures were discussed by the $\mathrm{N}_{2}$ adsorption-desorption analysis. According to the results of the nanostructure, characterization revealed that for synthesized $\gamma$-AlOOH nanostructures from $\mathrm{AlCl}_{3}$ and $\mathrm{Al}\left(\mathrm{NO}_{3}\right)_{3}$, obvious XRD peaks corresponding to the bayerite phase are found indicating an impure $\gamma$-AlOOH phase. Furthermore, the nitrogen adsorption-desorption analysis indicated that the obtained $\gamma$ - $\mathrm{AlOOH}$ nanoparticles from $\mathrm{Al}_{2}\left(\mathrm{SO}_{4}\right)_{3}$ of technical grade ( $95.0 \%$ of purity) and low cost, possess a high BET surface area of approximately $350 \mathrm{~m}^{2} / \mathrm{g}$, compared to the obtained nanostructures from aluminum sources reactive grade, which was attributed to the presence of $\mathrm{Mg}(0.9$ wt. \%) in its nanostructure.

Keywords: nanofibers; pseudoboehmite; aluminum source; hydrolysis-precipitation

\section{УЛОГА НА ПОТЕКЛОТО НА АЛУМИНИУМ КАКО ИЗВОР НА ФИЗИЧКОХЕМИСКИТЕ СВОЈСТВА НА НАНОЧЕСТИЧКИТЕ НА $\gamma$-AIOОН}

Подробно е испитна улогата на физичкохемиските својства на алуминиумовите соли во синтезата на наноструктурите на $\gamma$-AlOOH со примена на методот хидролиза-преципитација. За карактеризација на синтетизираните примероци се користени рендгенска флуоресценција (XRF), Фуриеова трансформирана инфрацрвена спектроскопија (FTIR), рендгенска дифракција на прашок (XRD), скенирачка електронска микроскопија на емисија на поле (FESEM) и трансмисиона електронска микроскопија (TEM). Специфичната површина, распределбата на димензиите на порите и пречникот на порите на разните структури на $\gamma$-AlOOH беа дискутирани врз основа на анализа на атсорпицја-десорпција на азот. Според резултатите на наноструктурата, карактеризацијата откри дека за наноструктури на $\gamma$ - $\mathrm{AlOOH}$, синтетизирани од $\mathrm{AlCl}_{3}$ и $\mathrm{Al}\left(\mathrm{NO}_{3}\right)$, се појавуваат очигледни XRD пикови што одговараат на бајерит-фаза, што укажува на нечиста $\gamma$ $\mathrm{AlOOH-фаза.} \mathrm{Исто} \mathrm{така,} \mathrm{анализата} \mathrm{на} \mathrm{атсорпција-десорпција} \mathrm{на} \mathrm{азот} \mathrm{покажува} \mathrm{дека}$ наночестичките на $\gamma$ - $\mathrm{AlOOH}$ добиени од технички (95.0\% чистота) и евтин $\mathrm{Al}_{2}\left(\mathrm{SO}_{4}\right)_{3}$ имаат висока BET површина од приближно $350 \mathrm{~m}^{2} / \mathrm{g}$ споредено со наноструктури од алуминиум со голема чистота, што се припишува на присуството на $\mathrm{Mg}(0.9 \mathrm{wt} . \%)$ во наноструктурата.

Клучни зборови: нановлакна; псевдобохемит; извор на алуминиум; хирдолиза-преципитација 


\section{INTRODUCTION}

Aluminum oxyhydroxides $(\gamma-\mathrm{AlOOH})$ are important industrial materials with important industrial applications [1]. They are the precursor of $\gamma-\mathrm{Al}_{2} \mathrm{O}_{3}[2]$ and other crystalline structures such as $\eta-, \delta-, \theta-, \kappa-, \chi-$ and $\alpha$-alumina [3]. The $\gamma-\mathrm{AlOOH}$ is widely used as a catalytic support and catalyst $[4,5]$, adsorbent [6], ceramic, abrasive and filter [7]. In addition, it is a low-cost material which has received considerable attention during the past decades $[4,6]$. In the area of catalysis, it exhibits catalytic activity in the process of methanol dehydration to dimethyl ether [8]. Furthermore, another study revealed that $\gamma$-AlOOH has a strong influence on the distribution of products for the hydrogenation of $\mathrm{CO}$ and shows excellent selectivity of acetaldehyde for the reaction of methanol and synthesis gas [9]. Bing et al. observed specific activity for the syngas conversion to ethanol [10] and it was recently found that the simple aluminum oxyhydroxide $(\gamma-\mathrm{AlOOH})$, as a solid acid catalyst, gave an attractive performance for the 3-methyl-2cyclopentenone generation from 2,5-hexanedione with high selectivity $(>71 \%)$ via hydrogenolysis and successive hydrolysis [11].

The $\gamma$-AlOOH has a layered structure with octahedral layers bonded together through hydrogen bonds [12], which contains a large number of available hydroxyl $(\mathrm{OH})$ groups to connect with a variety of nanostructured materials [13]. Therefore, researchers have broadly addressed the development of new routes to prepare $\gamma$-AlOOH structures [12-15]. The hydrolysis-precipitation route is one of the promising, mild and attractive methods for the synthesis of high-quality $\gamma$-AlOOH nanostructures. However, the effectiveness of this synthesis route depends on the experimental conditions (temperature and processing time, initial $\mathrm{pH}$ and the aluminum source) [16]. To date, $\gamma$-boehmite has been synthesized with different morphologies (whisker, single-crystal nanobelts, nanorods, nanoflakes, nanofibers and flower-like among others) and synthesis routes, as well as different experimental conditions [15-18]. Nonetheless, it is important to indicate that the potential applications of this material depend on its size and shape control. On the other hand, the stability and textural properties of nanostructures are crucial and determinant for current applications. Some authors have emphasized that materials with high pore volume may improve the adsorption performance if it is used as an adsorbent or catalyst material, and the loading capacity if is applied as a catalytic support. These properties improve the diffusion and transport of reagents and reactants [15, 19].
The basic or acidic, texture and stability properties of the nanostructures can be strongly influenced by the preparation route and conditions [20]. Different authors have shown that the properties of $\gamma$-boehmite, such as nanoparticle size, shape, and structure, depend on the synthetic conditions and the nature of the aluminum precursors and their degree of impurities [21]. Additionally, aluminum precursors with the presence of impurities may be used to obtain materials with interesting properties and applications. In our laboratory, we have reported that $\mathrm{Al}_{2} \mathrm{O}_{3}$ nanostructures synthesized using aluminum sulfate (technical grade with a purity of 95 $\%$ by weight) exhibited better textural properties than those obtained with aluminum sulfate (analytical grade with a purity of $99.98 \%$ by wt.), due to improvement by the presence of small amounts of impurities, such as $\mathrm{Mg}$ (0.33 wt.\%) [22].

Undoubtedly, the research and development of producing $\gamma$-AlOOH with various structures is beneficial for many branches of modern science and technology. However, reports concerning the synthesis of $\gamma$-AlOOH by a simple, environmentally favorable, and low-cost synthesis method with interesting textural properties are still limited. This work aimed to study the effect of the purity of the aluminum source (chloride, nitrate and two different aluminum sulphates) on the textural properties of $\gamma$-AlOOH nanoparticles via a hydrolysisprecipitation route. The chemical composition, structure, and morphology were investigated by the XRF, XRD, FTIR, $\mathrm{N}_{2}$ adsorption-desorption, FESEM and TEM studies.

\section{EXPERIMENTAL SECTION}

\subsection{Chemicals}

The following chemicals were used: $\mathrm{Al}_{2}\left(\mathrm{SO}_{4}\right)_{3} \cdot 18 \mathrm{H}_{2} \mathrm{O}, \quad \mathrm{AlCl}_{3} \cdot 6 \mathrm{H}_{2} \mathrm{O}, \quad \mathrm{Al}\left(\mathrm{NO}_{3}\right)_{3} \cdot 9 \mathrm{H}_{2} \mathrm{O}$ chemical reagents analytical grade were purchased from Sigma-Aldrich, México and aluminum sulfate $\mathrm{Al}_{2}\left(\mathrm{SO}_{4}\right)_{3} \cdot 18 \mathrm{H}_{2} \mathrm{O}$ (technical grade, $95.0 \%$ of purity) was purchased from Alfa-Omega Chemical S.A de C.V. México. Anhydrous ammonia gas (purity $\geq 99.98 \%$ ) was purchased from Praxair; México, and distilled water was provided by the University of Guanajuato.

\subsection{Pseudoboehmite synthesis}

Initially, $100 \mathrm{~g}$ of each aluminum precursor was dissolved into distilled water and stored before the experiment. The $\mathrm{Al}_{2}\left(\mathrm{SO}_{4}\right)_{3} \cdot 18 \mathrm{H}_{2} \mathrm{O}$ (technical grade) was filtered using milli-pore filter paper for 
removal of insoluble impurities. In order to study the effects of the different kinds of $\mathrm{Al}$ resources on the physico-chemical properties, the experiments were carried out similarly. First, $1000 \mathrm{ml}$ of the aqueous solution was added to a solution of water and ammonia gas at a rate of $1000 \mathrm{ml} / \mathrm{h}$ using a peristaltic pump (Cole palmer instrument Co., USA), under rigorous mechanical agitation (400 rpm), at a temperature of $65 \pm 1^{\circ} \mathrm{C}$ to reach a $\mathrm{pH}$ of 9 to 11 (depending on the aluminum precursor). After aging for $20 \mathrm{~min}$ at the same temperature, the obtained precipitate was filtered and washed three times, with cold and hot distilled water, to remove $\mathrm{SO}_{4}{ }^{2-}$ completely $\left(\mathrm{BaCl}_{2}\right.$ detection). The precipitate was dried in an oven at $\sim 110^{\circ} \mathrm{C}$ for $12 \mathrm{~h}$.

The overall reactions leading to the formation of pseudoboehmite using different aluminum salts can be represented by Eqs. (1) - (3).

$$
\mathrm{Al}_{2}\left(\mathrm{SO}_{4}\right)_{3}+6 \mathrm{NH}_{3}+6 \mathrm{H}_{2} \mathrm{O} \rightarrow 2 \mathrm{AlOOH}+3\left(\mathrm{NH}_{4}\right)_{2} \mathrm{SO}_{4}+2 \mathrm{H}_{2} \mathrm{O}
$$

$$
2 \mathrm{AlCl}_{3}+6 \mathrm{NH}_{3}+6 \mathrm{H}_{2} \mathrm{O} \rightarrow 2 \mathrm{AlOOH}+6 \mathrm{NH}_{4} \mathrm{Cl}+2 \mathrm{H}_{2} \mathrm{O}
$$

$$
\begin{gathered}
\mathrm{Al}\left(\mathrm{NO}_{3}\right)_{3}+3 \mathrm{NH}_{3}+3 \mathrm{H}_{2} \mathrm{O} \rightarrow \mathrm{Al}(\mathrm{OH})_{3}+3 \mathrm{NH}_{4} \mathrm{NO}_{3} \\
\mathrm{Al}(\mathrm{OH})_{3} \rightarrow \mathrm{AlOOH}+\mathrm{H}_{2} \mathrm{O}
\end{gathered}
$$

\subsection{Characterization}

The elemental chemical quantifications were determined by high-resolution wavelength dispersive-X-ray fluorescence spectra (XRF) were recorded by a NEX-CG RIGAKU spectrometer of cartesian geometry, equipped with a Pd anode Xray tube. Fourier transform infrared (FTIR) spectra were obtained using an FT-IR Nicolet 470 spectrometer in the range $400-4000 \mathrm{~cm}^{-1}$ at room temperature. The X-ray powder diffraction (XRD) pat- terns were identified using a Siemens D-500 X-ray diffractometer, equipped with $\mathrm{CuK} \alpha$ radiation $(\lambda=$ $1.54 \AA$ ). Data were collected from 10 to $80^{\circ}(2 \theta)$, with a scan rate of $0.03 \%$. The microstructures were studied by transmission electron microscopy (TEM) using a Philips Tecnai F20 microscope operated at $200 \mathrm{kV}$, while the surface morphology of the samples were investigated with a fieldemission scanning electron microscope (JEOL JSM 7600-F). Surface area, pore volume, and pore size distribution were determined by $\mathrm{N}_{2}$ adsorption-desorption with a Micromeritics, ASAP 2010. The samples were degassed at $150{ }^{\circ} \mathrm{C}$ for $3 \mathrm{~h}$, under vacuum. Nitrogen adsorption isotherms were measured at liquid $\mathrm{N}_{2}$ temperature $(77 \mathrm{~K})$, and $\mathrm{N}_{2}$ pressures ranging from $10^{-6}$ to $1.0 \mathrm{P} / \mathrm{P}_{0}$. The specific surface areas were calculated by means of the Brunauer-Emmett-Teller (BET) method and the pore size distribution was obtained according to the Barret-Joyner-Halenda (BJH) method.

\section{RESULTS AND DISCUSSION}

\section{1. $X$-ray fluorescence $(X R F)$}

The quantitative chemical analysis (XRF) results are presented in Table 1 . As expected, the aluminum $(\mathrm{Al})$ and oxygen $(\mathrm{O})$ content dominate in the four salts studied. The $\mathrm{Al}_{2}\left(\mathrm{SO}_{4}\right)_{3}-\mathrm{A}$ and $\mathrm{Al}_{2}\left(\mathrm{SO}_{4}\right)_{3}-\mathrm{B}$ samples present a similar content of sulfur (S). The $\mathrm{AlCl}_{3}-\mathrm{C}$ sample has a high chlorine (Cl) content, due to its nature. However, the $\mathrm{Al}_{2}\left(\mathrm{SO}_{4}\right)_{3}$-A exhibits the presence of magnesium $(\mathrm{Mg})$, attributed to the impurity degree of the precursor, which has also been reported in previous works [16, 23].

Table 1

$X R F$ results of the average chemical composition of the aluminum source and synthesized pseudoboehmite

\begin{tabular}{ccccccccc}
\hline \hline Samples & \multicolumn{7}{c}{ Concentration $(\%)^{\mathbf{a}}$} \\
\hline Aluminum source & $\mathrm{Al}$ & $\mathrm{Si}$ & $\mathrm{S}$ & $\mathrm{Mg}$ & $\mathrm{Cl}$ & $\mathrm{Ca}$ & $\mathrm{Fe}$ & $\mathrm{O}$ \\
\hline $\mathrm{Al}_{2}\left(\mathrm{SO}_{4}\right)_{3}-\mathrm{A}$ & 7.53 & 0.06 & 13.8 & 1.1 & 0.0 & 0.01 & 0.01 & 78.5 \\
$\mathrm{Al}_{2}\left(\mathrm{SO}_{4}\right)_{3}-\mathrm{B}$ & 7.88 & 0.08 & 14.5 & 0.0 & 0.0 & 0.0 & 0.01 & 77.5 \\
$\mathrm{AlCl}_{3}-\mathrm{C}$ & 5.47 & 0.06 & 0.24 & 0.0 & 11.6 & 0.02 & 0.0 & 82.6 \\
$\mathrm{Al}\left(\mathrm{NO}_{3}\right)_{3}-\mathrm{D}$ & 6.3 & 0.02 & 0.01 & 0.0 & 0.0 & 0.0 & 0.0 & 93.7 \\
\hline Pseudoboehmite & & & & & & & & \\
\hline$\gamma$-AlOOH-A & 38.0 & 0.04 & 0.4 & 0.9 & 0.0 & 0.0 & 0.0 & 60.5 \\
$\gamma$-AlOOH-B & 38.1 & 0.02 & 0.06 & 0.0 & 0.0 & 0.0 & 0.0 & 61.8 \\
$\gamma$-AlOOH-C & 36.1 & 0.03 & 0.0 & 0.0 & 0.03 & 0.0 & 0.0 & 63.0 \\
$\gamma$-AlOOH-D & 36.1 & 0.04 & 0.0 & 0.0 & 0.0 & 0.0 & 0.0 & 63.8 \\
\hline \hline
\end{tabular}

aPercentage extraction values are based on triplicate analysis 
Also, the presence of silicon $(\mathrm{Si})$, calcium (Ca) and iron $(\mathrm{Fe})$ in small quantities in the four samples were reported. Furthermore, the results of the as-synthesized samples of pseudoboehmite are also given in Table 1, and which exhibit a higher concentration of $\mathrm{Al}$ and $\mathrm{O}$. This is consistent with the chemical formula of $\gamma-\mathrm{AlOOH}$. The presence of 0.4 wt. $\%$ of $\mathrm{S}$ in the sample $\gamma-\mathrm{AlOOH}-\mathrm{A}$ was also observed, attributed to ammonium sulfate $\left(\left(\mathrm{NH}_{4}\right)_{2} \mathrm{SO}_{4}\right)$ as a residue generated during the synthesis process. Besides that, the presence of $\mathrm{Mg}$ decreased, which is attributed to the fact that the 0.2 wt.\% was removed during the synthesis process and washes.

\subsection{X-ray powder diffraction $(X R D)$}

The phase structure and purity of the aluminum salts of the as-synthesized samples were examined by XRD. The XRD patterns of the aluminum sources are shown in Figure 1a), and the XRD patterns of the as-synthesized samples in Figure 1b). The salts of $\mathrm{Al}_{2}\left(\mathrm{SO}_{4}\right)_{3}$ - $\mathrm{A}$ and $\mathrm{B}$ show signals of peaks at $2 \theta$ of $12.51^{\circ}, 21.06^{\circ}, 25.55^{\circ}, 30.76^{\circ}$, $33.73^{\circ}, 40.99^{\circ}, 44.38^{\circ}$ and $46.81^{\circ}$, which are in line with those reported by other authors [23, 24]. No impurities-related signals were detected in $\mathrm{Al}_{2}\left(\mathrm{SO}_{4}\right)_{3}-\mathrm{A}$ and $\gamma$-AlOOH-A as $\mathrm{Mg}$, attributed to a homogeneous dispersion in the structure. The $\mathrm{AlCl}_{3}-\mathrm{C}$ salt diffraction pattern agrees with its crystallographic card (JDCPS card No. 44-1473) corresponding to $\mathrm{AlCl}_{3} \cdot 6 \mathrm{H}_{2} \mathrm{O}$, with the main peaks at $2 \theta=15.07,27.19,27.52,35.05,39.01,41.38$, 43.33 and $51.94^{\circ}$ with rhombohedral geometry [25, $26]$. On the other hand, the $\mathrm{Al}\left(\mathrm{NO}_{3}\right)_{3}-\mathrm{D}$ diffractogram shows the crystalline phase corresponding to $\mathrm{Al}\left(\mathrm{NO}_{3}\right)_{3} \cdot 9 \mathrm{H}_{2} \mathrm{O}$ presenting similar characteristic peaks as previously reported by Pacewsca [27] and Karimi [28]. The different aluminum precursors have different degrees of crystallinity. These aluminum precursors exhibit the following order: $\mathrm{Al}\left(\mathrm{NO}_{3}\right)_{3}-\mathrm{D}>\mathrm{AlCl}_{3}-\mathrm{C}>\mathrm{Al}_{2}\left(\mathrm{SO}_{4}\right)_{3}-\mathrm{A}>\mathrm{Al}_{2}\left(\mathrm{SO}_{4}\right)_{3}-$ $\mathrm{B}$. The above indicates that the size of crystals present in the aluminium sulfate hydrate is finer than the other aluminum sources.

Figure 1b) shows the XRD patterns of the samples synthesized in this research. All diffraction peaks of the pseudoboehmite nanoparticles were in good agreement with $\gamma$-AlOOH (JCPDS no. 21-1307), which is the orthorhombic cell with lattice parameters of $a=3.78 \AA, b=11.8 \AA$, and $c$ $=2.85 \AA[29,30]$. The diffraction pattern reveals the well-defined peaks at the angles of 14.3, 28.1, $38.3,45.7,48.9,51.6,54.9,64.6,66.7$, and $72.1^{\circ}$ corresponded to the (020), (120), (140), (131), (200), (160), (151), (071), (022) and (251) planes of the orthorhombic pseudoboehmite, respectively. The orthorhombic structure of $\gamma-\mathrm{AlOOH}$ is proved by comparing the XRD pattern with those reported in the literature [7, 10]. X-ray diffractograms of samples $\gamma$-AlOOH-C and $\gamma$-AlOOH-B show characteristic peaks of $\gamma-\mathrm{AlOOH}$. However, it also shows four peaks at $2 \theta(19.05,20.05,41.0$ and $\left.53.0^{\circ}\right)$ which do not correspond to the pseudoboehmite phase, indicating that the materials exhibited an additional crystalline phase of bayerite. This result indicates an impure $\gamma-\mathrm{AlOOH}$ phase [31].
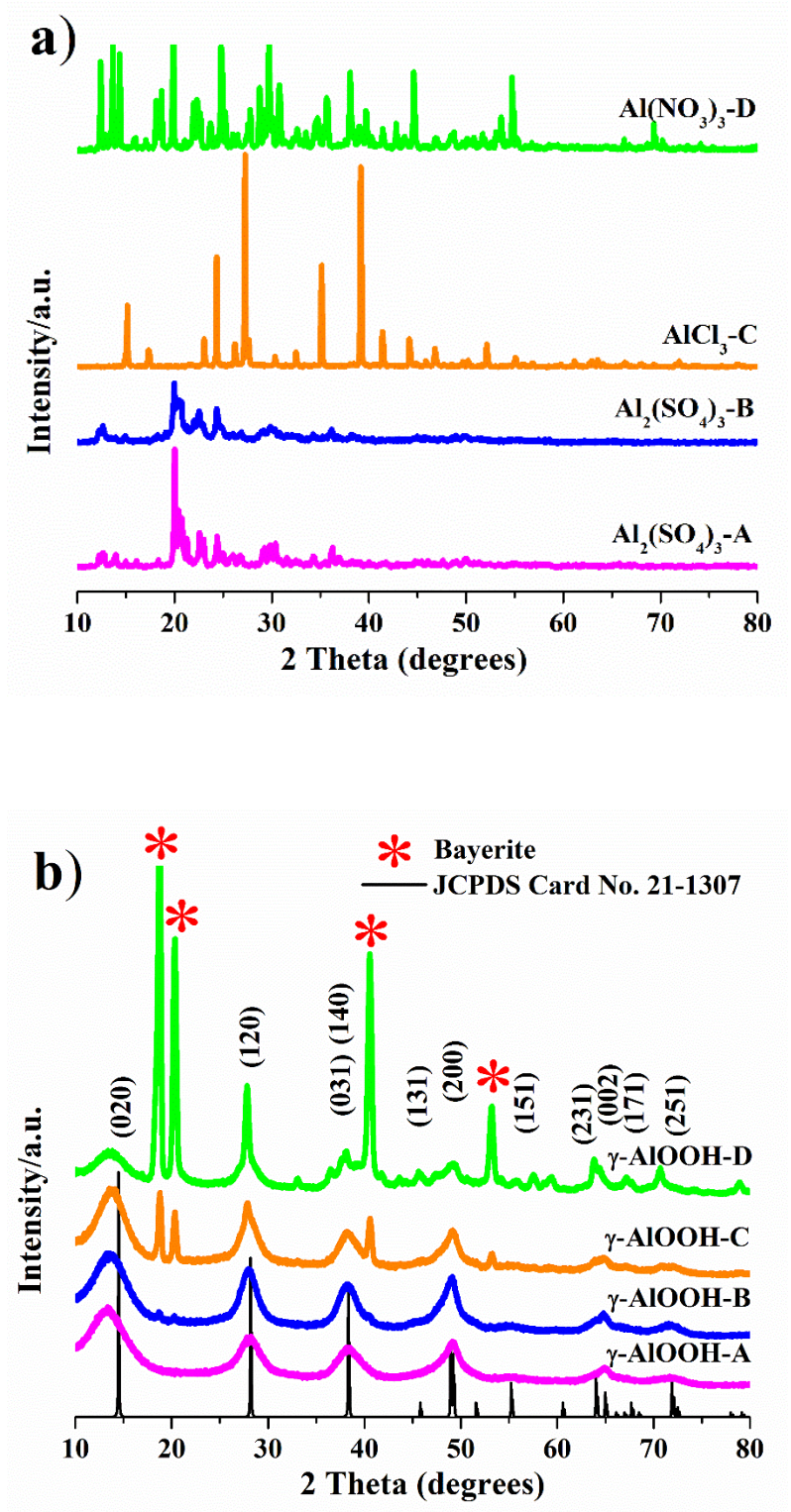

Fig. 1. X-ray powder diffraction of a) aluminum source and b) as-synthesized samples 
Previous studies have reported that when $\mathrm{AlCl}_{3}$ and $\mathrm{Al}\left(\mathrm{NO}_{3}\right)_{3}$ salts are used to obtain pseudoboehmite, the formation of additional crystalline phases such as gibbsite and bayerite can appear. The presence of these crystalline phases is due to experimental parameters that were directly influenced by the $\mathrm{pH}$ and the precursors [32]. It has been reported that bayerite $\mathrm{Al}(\mathrm{OH})_{3}$ formation could be obtained at alkaline $\mathrm{pH}$ values $(\mathrm{pH} \mathrm{11)}$, together with a weak XRD peak assigned to boehmite from nitrate precursors. On the other hand, at lower $\mathrm{pH}$, the crystalline phase in the samples changed to pseudoboehmite, whose peaks became broader [33]. This work showed a similar behavior with aluminum salts (nitrate or chloride) which reached $\mathrm{pH} 11$ during the synthesis process, but not for aluminum sulphate salts with a $\mathrm{pH}$ 9. It is known that the physicochemical properties can be very different for low- and well-crystallized pseudoboehmite, even though their crystal structure is just the same. Furthermore, there is an evident shift of the diffraction lines of $\gamma$-AlOOH-C and $\gamma-\mathrm{AlOOH}-\mathrm{D}$, which suggests that the layers are rotated or displayed due to the change of $\mathrm{pH}$ or aluminium salt. It is noteworthy, that compared with the XRD pattern of $\gamma-\mathrm{AlOOH}-\mathrm{B}$, the sample $\gamma$-AlOOH-A demonstrated wider peaks; this represents an increase in the lattice parameter values. The increase in the spacing confirms that $\mathrm{Mg}$ is present in the framework of $\gamma-\mathrm{AlOOH}-\mathrm{A}$. This attribution is made due to the contribution of other authors, where they mention that the incorporation of $\mathrm{Mg}$ generates the formation of $\mathrm{Mg}-\mathrm{O}$ bonds with lengths longer than that of the $\mathrm{Al}-\mathrm{O}$ bonds, resulting in a mesostructural expansion [22].

\subsection{Fourier transform infrared spectroscopy (FTIR)}

The FTIR analysis of $\gamma$-AlOOH is characterized by prominent $\mathrm{OH}$ stretching and bending modes associated with the interlayer hydrogen bonds of the structure in terms of vibration intensity and frequency [32]. Figure 2 shows the infrared spectra of synthesized samples of $\gamma-\mathrm{AlOOH}$. In general, all the FTIR spectra are similar regardless of the slight difference in intensities of some peaks, and one additional peak for the synthesized samples from aluminum salts (nitrate or chloride). The FTIR spectra demonstrate the typical spectra of pseudoboehmite [32, 34]. Firstly, for the samples $\gamma$-AlOOH-A and $\gamma$-AlOOH-B, intensive bands at 3443 and $3090 \mathrm{~cm}^{-1}$ are observed, while for the samples $\gamma$-AlOOH-C and $\gamma$-AlOOH-D bands are observed at 3650, 3575, 3443 and $3090 \mathrm{~cm}^{-1}$. All bands belong to the $v_{\mathrm{s}}(\mathrm{Al}) \mathrm{O}-\mathrm{H}$ and $v_{\text {as }}(\mathrm{Al}) \mathrm{O}-\mathrm{H}$ stretching vibrations or $\mathrm{O}-\mathrm{H}$ stretching mode [3437]. The band at $3443 \mathrm{~cm}^{-1}$ for the samples $\gamma$ $\mathrm{AlOOH}-\mathrm{A}$ and $\gamma-\mathrm{AlOOH}-\mathrm{B}$ dominates this region and prevents the observation of the features corresponding to the structural $\mathrm{OH}$ groups for the pseudoboehmite phase. The weak band at $2095 \mathrm{~cm}^{-1}$ is the combination band $[35,36]$. The weak band at $1638 \mathrm{~cm}^{-1}$ can be assigned to the stretching and bending modes of the adsorbed water molecules and this absorbance in the spectra of $\gamma-\mathrm{AlOOH}$ nano-architectures is very weak for $\gamma-\mathrm{AlOOH}-\mathrm{C}$ and $\gamma-\mathrm{AlOOH}-\mathrm{D}$, indicating a very small amount of physically adsorbed water molecules. This result is consistent with the XRD patterns (Figure 1b), because it exhibits a major crystalline structure compared to $\gamma-\mathrm{AlOOH}-\mathrm{A}$ and $\gamma-\mathrm{AlOOH}-\mathrm{B}$. It has been reported that the bands at around 1420 and $1510 \mathrm{~cm}^{-1}$ are due to the amorphous surface structure existing in nanocrystalline pseudoboehmite. This explains the vibrations observed at $\sim 1389$ and $1507 \mathrm{~cm}^{-1}$ in our synthesized pseudoboehmite [36]. While the sharp peak at $1072 \mathrm{~cm}^{-1}$ and small shoulder at $1171 \mathrm{~cm}^{-1}$ are assigned to the angle bending of the $\mathrm{H}$ bonds in the octahedral structure of pseudoboehmite $(\mathrm{HO}-\mathrm{Al}=\mathrm{O})$ and the angle deformation (wagging) of the $\mathrm{H}$ bonds in the octahedral structure of pseudoboehmite $(\mathrm{HO}-\mathrm{Al}=\mathrm{O})$, respectively [32, 36, 37]. The bands at 750, 625 and $490 \mathrm{~cm}^{-1}$ are ascribed to the vibration modes of $\mathrm{AlO}_{6}$, while a band at $882 \mathrm{~cm}^{-1}$ is ascribed to the stretching mode of $\mathrm{AlO}_{4}[32,34,36,37]$. The main bands are listed in Table 2, together with their assignment, and compared with those reported in the literature.

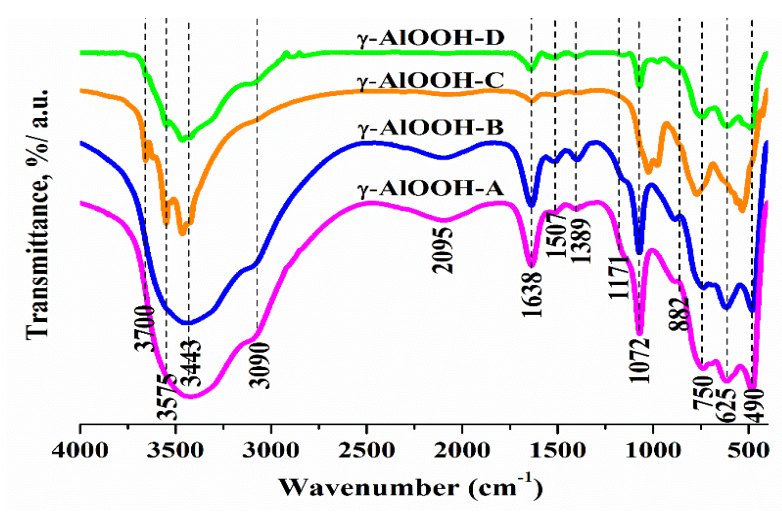

Fig. 2. FTIR spectra of as-synthesized samples 
Table 2

Pseudoboehmite FTIR band positions measured on our samples together with values and assignments reported in the literature

\begin{tabular}{|c|c|c|}
\hline \multicolumn{2}{|c|}{ Pseudoboehmite band position $\left(\mathrm{cm}^{-1}\right)$} & \multirow[b]{2}{*}{ Assignment (from reported [32-37]) } \\
\hline This work & $\begin{array}{l}\text { From reported } \\
{[32-37]}\end{array}$ & \\
\hline 3650 & 3628 & $\begin{array}{l}\text { vas }(\mathrm{Al}) \mathrm{O}-\mathrm{H} \text { and } v_{\mathrm{s}}(\mathrm{Al}) \mathrm{O}-\mathrm{H} \text { stretching vibrations } \\
\text { or } \mathrm{O}-\mathrm{H} \text { stretching mode. }\end{array}$ \\
\hline 3575 & - & \\
\hline 3443 & $3440,3445,3460$ & \\
\hline 3090 & 3080, 3095, 3098 & \\
\hline 2095 & 2091, 2092 & $\mathrm{H}-\mathrm{O}-\mathrm{H}$ bonds \\
\hline 1638 & $1630,1634,1635,1638,1640$ & Hydroxyl bands on the surface \\
\hline 1507 & 1510,1520 & Amorphous surface structure \\
\hline 1389 & $1384,1387,1389,1400,1420$ & $\mathrm{H}_{2} \mathrm{O}$ deformation vibrations and or vibration of $\mathrm{NO}_{3}$ \\
\hline 1171 & $1156,1160,1170$ & $\begin{array}{l}\text { Angle deformation (wagging) of the } \mathrm{H} \text { bonds in the } \\
\text { octahedral structure of pseudoboehmite }(\mathrm{HO}-\mathrm{Al}=\mathrm{O})\end{array}$ \\
\hline 1072 & $1065,1072,1073,1075$ & $\begin{array}{l}\text { Angle bending of the } \mathrm{H} \text { bonds in the octahedral } \\
\text { structure of pseudoboehmite }(\mathrm{HO}-\mathrm{Al}=\mathrm{O})\end{array}$ \\
\hline 882 & 884 & Stretching mode of $\mathrm{AlO}_{4}$ \\
\hline 750 & $720,746,747,760$ & Vibration modes of $\mathrm{AlO}_{6}$ \\
\hline 625 & 631,633 & \\
\hline 490 & 480,491 & \\
\hline
\end{tabular}

\section{4. $N_{2}$ adsorption-desorption}

Figure 3 shows the $\mathrm{N}_{2}$ adsorptiondesorption isotherm measured at $77 \mathrm{~K}$ and the corresponding pore size distributions curves (inset) calculated via the Barret-Joyner-Halenda (BJH) of the synthesized pseudoboehmite samples. All samples exhibit IV-type isotherm (definition by IUPAC) $[32,36]$ and, as indicated by the convex curvature of the isotherms at the sub-monolayer range and by the occurrence of a narrow hysteresis loop at high $\mathrm{P} / \mathrm{P}_{0}$ range, it shows that these pseudoboehmite were mesoporous materials [36]. The appearance of a type $\mathrm{H}_{2}$ hysteresis loop in the isotherm indicates the presence of ink-bottle type pores in the mesoporous pseudoboehmite. This indicates that they have good pore connectivity [32]. Table 1 lists the results of specific surface area (SSA), pore volume $\left(V_{\mathrm{P}}\right)$ and average pore diameter $\left(D_{P}\right)$ of the synthesized $\gamma-\mathrm{AlOOH}$ nanostructures, values reported in the literature, and preparation conditions. These results show that the source of aluminum is crucial to the preparation of $\gamma-\mathrm{AlOOH}$ by the hydrolysis-precipitation method. It can be seen that the pore sizes for all synthesized samples were located between 2-17 $\mathrm{nm}$, respectively.

All samples synthesized have a high surface area $\left(327-350 \mathrm{~m}^{2} / \mathrm{g}\right)$, which could be ranked in the following order: $\gamma$-AlOOH-A $>\gamma$-AlOOH-D $>\gamma$ -
$\mathrm{AlOOH}-\mathrm{C}>\gamma$-AlOOH-B. The samples synthesized by nitrates and chlorides did not show significant changes in the surface area, even with their greater crystalline structure and the presence of bayerite as an additional phase, as shown in Figure $1 b)$. On the other hand, the $\gamma$-AlOOH-A sample exhibited a higher specific surface area $\left(350 \mathrm{~m}^{2} / \mathrm{g}\right)$. Nonetheless, the obtained textural properties for sample $\gamma$-AlOOH-A is comparable and higher than other pseudoboehmites and boehmites reported in the literature, as shown in Table 3.

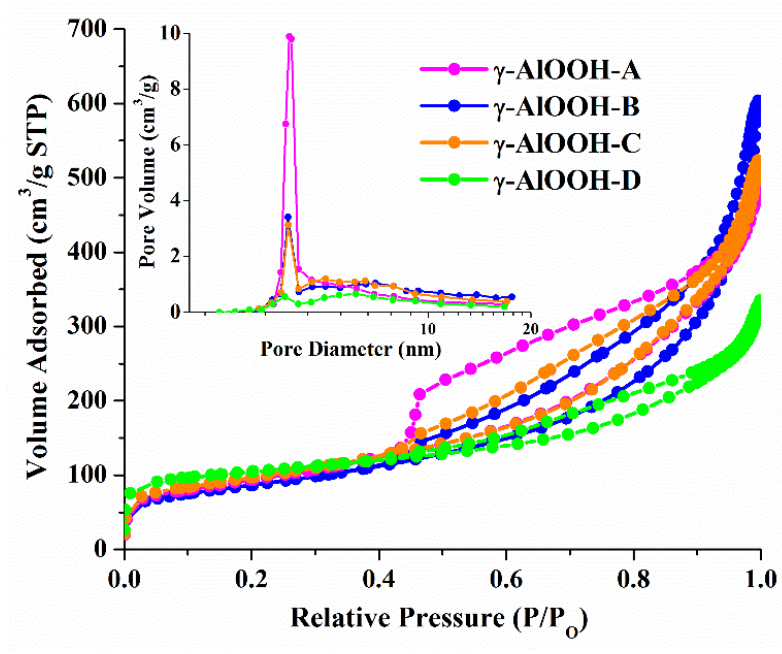

Fig. 3. Nitrogen adsorption/desorption isotherms and corresponding BJH pore size distribution of the as-synthesized samples. 
Until now, few reports are available on the direct synthesis of mesoporous $\mathrm{Mg}-\mathrm{AlOOH}$ composite oxyhydroxides of low-cost with a longrange mesostructured, high specific surface area and pore volume, and a highly homogeneous presence of $\mathrm{MgO}$ as an impurity. These results suggest that aluminum precursors with a considerable de- gree of impurities are a more economical, easy, environmentally friendly and convenient synthesis procedure with better textural properties for mesoporous pseudoboehmite particles. In general, larger specific surface area and pore volume are favorable for many applications such as catalyst support, and absorbance.

T a b l e 3

Preparation conditions and textural properties of the synthesized pseudoboehmite samples and values reported in the literature

\begin{tabular}{|c|c|c|c|c|c|c|}
\hline $\begin{array}{c}\text { As-synthesized } \\
\text { powder }\end{array}$ & $\begin{array}{c}\text { Temperature } \\
\left({ }^{\circ} \mathrm{C}\right)\end{array}$ & $\begin{array}{c}\text { Solution } \\
\text { pH range }\end{array}$ & SSA $\left(\mathrm{m}^{2} / \mathrm{g}\right)$ & $V_{P}\left(\mathrm{~cm}^{3} / \mathrm{g}\right)$ & $\mathbf{D}_{\mathbf{P}}(\AA)$ & Refs. \\
\hline$\gamma$-AlOOH-A & $65 \pm 2$ & $9-10$ & 350 & 0.77 & 85 & This work \\
\hline$\gamma$-AlOOH-B & $65 \pm 2$ & $9-10$ & 327 & 0.74 & 80 & This work \\
\hline$\gamma$-AlOOH-C & $65 \pm 2$ & $10-11$ & 335 & 0.62 & 80 & This work \\
\hline$\gamma$-AlOOH-D & $65 \pm 2$ & $10-11$ & 340 & 0.30 & 62 & This work \\
\hline C-5 & 180 & 5 & 48 & 0.37 & 166 & {$[32]$} \\
\hline C-11 & 180 & 11 & 39 & 0.35 & 280 & [32] \\
\hline $\mathrm{N}-5$ & 180 & 5 & 48 & 0.35 & 287 & [32] \\
\hline $\mathrm{N}-11$ & 180 & 11 & 46 & 0.27 & 300 & {$[32]$} \\
\hline ATG1-25 & 25 & $10.8-12$ & 393 & 0.29 & 29 & {$[36]$} \\
\hline ATG2-25 & 25 & $9.5-10.8$ & 350 & 0.5 & 28 & [36] \\
\hline Synthetic Boehmite & 95 & - & 198 & - & 40 & {$[38]$} \\
\hline Boehmite & 180 & 8.5 & 98.6 & - & - & {$[31]$} \\
\hline LP & 60 & 9.7 & 273 & 0.66 & 75 & {$[20]$} \\
\hline $\mathrm{AlO}(\mathrm{OH})-\mathrm{NR}$ & 70 & $9-10$ & 448 & - & 20 & [39] \\
\hline Pseudoboehmite & - & 10.5 & 350 & 0.49 & 53 & {$[40]$} \\
\hline $\mathrm{AlOOH}$ & 80 & - & 385 & 0.28 & 28 & [15] \\
\hline$\gamma-\mathrm{AlOOH}$ & 150 & - & 225 & 0.45 & $56-82$ & [41] \\
\hline
\end{tabular}

\subsection{Field-emission scanning electron microscopy (FESEM)}

The microstructure of the synthesized $\gamma$ AlOOH nanoparticles was studied using FESEM. Figure 4 shows the representative images of a) $\gamma$ $\mathrm{AlOOH}-\mathrm{A}, \mathrm{b}) \gamma$-AlOOH-B, c) $\gamma$-AlOOH-C, and d) $\gamma$-AlOOH-D, respectively. According to FESEM images, different sources of aluminum have a fundamental effect on the morphologies of asprepared $\gamma-\mathrm{AlOOH}$ by the hydrolysis-precipitation route. The obtained images indicate that the $\gamma$ $\mathrm{AlOOH}-\mathrm{A}, \gamma-\mathrm{AlOOH}-\mathrm{B}$ and $\gamma-\mathrm{AlOOH}-\mathrm{C}$ samples have a sponge-like morphology, while the $\gamma$ AlOOH-D sample showed irregular crystalline agglomerates (not nanostructured). Furthermore, obvious agglomeration phenomena can be observed in the samples due to the effect of surface functional groups and quantum size [42]. This fact evidences the differences between the samples ob- tained by hydrolysis-precipitation method, showing amorphous nanofibrous agglomerates for the samples (a, b and c) due to their high surface energy, so generating a high porosity. However, regarding sample (d), it exhibits a high degree of crystallinity, (Fig. 1b) and, thus, has many small pores, causing a low pore volume and diameter (Table 3). The reason leading to this phenomenon may be that the pore structures were occupied by water during the polymerization process. The fibers' length is approximately $100 \mathrm{~nm}$ and the diameter approximately $20 \mathrm{~nm}$. This means that the crystals grew faster in the longitudinal direction than in the diametrical direction. The nano-fibers are tangled with a smooth surface. It can be appreciated that the formed nanoparticles for $\gamma-\mathrm{AlOOH}-$ $\mathrm{A}, \gamma-\mathrm{AlOOH}-\mathrm{B}$, and $\gamma-\mathrm{AlOOH}-\mathrm{C}$ samples possess uniform pore size distribution and are homogeneous without preferentially oriented shapes, while the $\gamma$-AlOOH-D sample indicate a totally different 
morphology (small plate-like structures). Due to this structure, there are lots of defects on secondary particles, inducing a larger amount of pores between primary crystallites, and these pores are very small. This is why sample $\gamma$-AlOOH-D has a high SSA. When the primary crystallites are well crystalline, the corresponding secondary particles have few defects and most pores arise from the packing spaces between secondary particles. Nevertheless, it has been observed that the structure and physicochemical properties not only depend on the aluminum source, but also that they are strongly influenced by the synthesis method and its conditions.

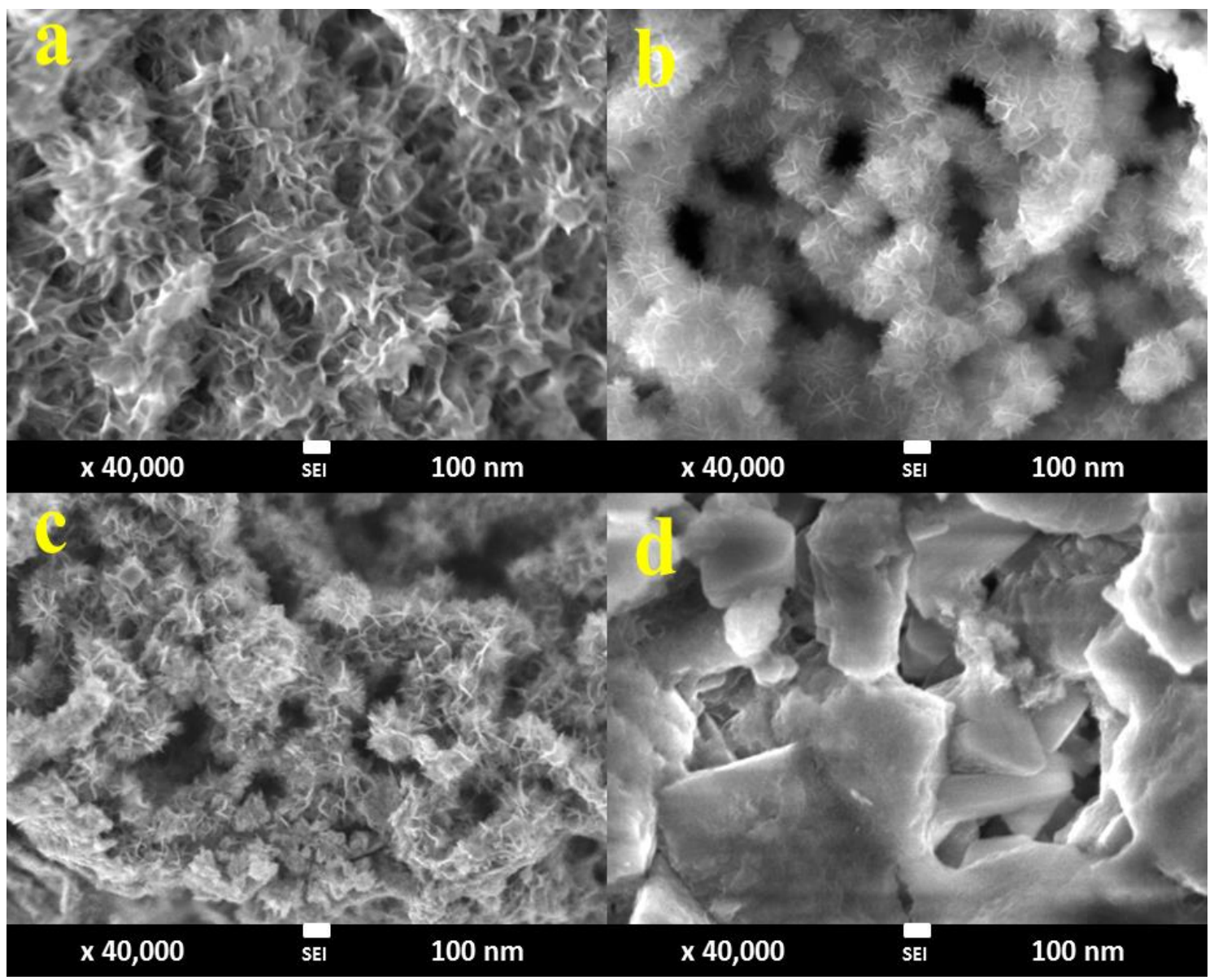

Fig. 4. FESEM images of pseudoboehmite samples, a) $\gamma$-AlOOH-A, b) $\gamma$-AlOOH-B, c) $\gamma$-AlOOH-C, d) $\gamma$-AlOOH-D

\subsection{Transmission electron microscope (TEM)}

TEM micrographs of aluminum oxyhydroxide nanoparticles are given in Figure 5. All particles exhibit similar shapes and morphologies. However, slight changes in the morphological nano-fibrillary messy substructure were observed: a length of approximately $100 \mathrm{~nm}$ for the $\gamma$-AlOOH-A sample and $80 \mathrm{~nm}$ for $\gamma$-AlOOH-B, while for $\gamma-\mathrm{AlOOH}-\mathrm{C}$, a nanofibrillar length of $60 \mathrm{~nm}$ can be observed. Finally, the $\gamma$-AlOOH-D sample has very small nanofibers of about $33 \mathrm{~nm}$ in length. The results show that the length and thickness plays a key role in the textural and crystallinity properties. The shorter nanofibers induce a greater crystallinity, and therefore, reduced textural properties due the overlap and the closely spaced nanofibers. The textural properties and X-ray diffraction analysis back up these results obtained by TEM analysis. The results obtained by the TEM analysis for nanofiber lengths presented the following order: $\gamma$-AlOOH-A $>\gamma$-AlOOH-B > $\gamma$-AlOOH-C $>\gamma$-AlOOH-D, which are in accordance with those obtained in the pore size distribution (Fig. 3). 


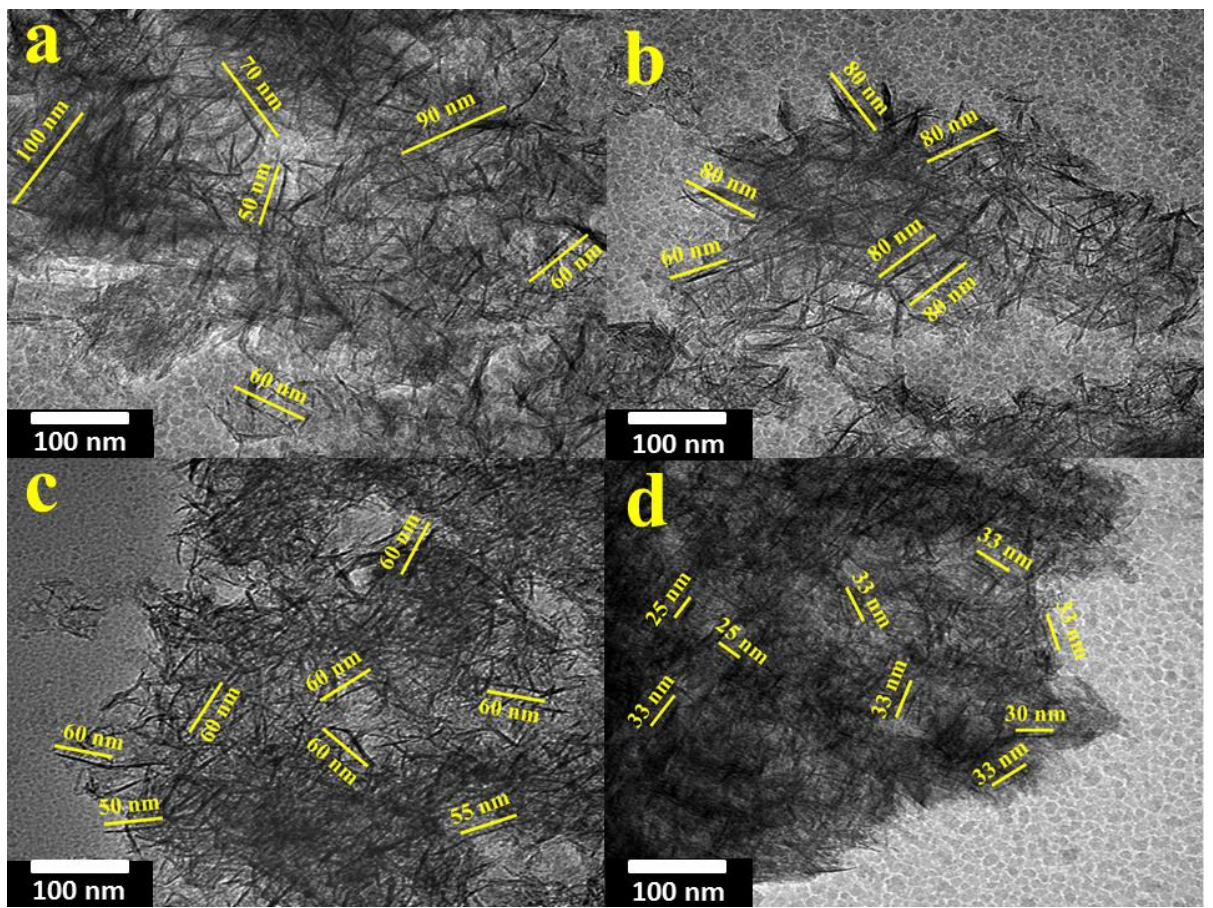

Fig. 5. TEM images of the pseudoboehmite nanostructures, a) $\gamma$-AlOOH-A, b) $\gamma$-AlOOH-B, c) $\gamma$-AlOOH-C and d) $\gamma$-AlOOH-D

\section{CONCLUSIONS}

In this paper, the simple synthesis of pseudoboehmite nanostructures using diverse aluminum sources at low temperature has been reported. The above mentioned was done, without using any surfactant or template. It is possible to obtain the pseudoboehmite phase from $\mathrm{Al}_{2}\left(\mathrm{SO}_{4}\right)_{3}$ technical grade, of low-cost, through the hydrolysis-precipitation route. The mesoporous pseudoboehmite shows a high specific surface area $\left(350 \mathrm{~m}^{2} / \mathrm{g}\right)$ which is comparable with other materials fabricated using analytical grade precursors. The possible use of a low-temperature, mild and environmentally friendly synthesis, with high impact regarding the costs of precursors and energy consumption during the production of $\gamma$-AlOOH nanopowders, is presented as an alternative. The advantages of these nanostructures include their simplicity, lowcost and versatility with a wide range of applications in ceramics, adsorption, catalyst and catalyst supports and moreover, complex apparatus is not needed.

Acknowledgements. The authors gratefully acknowledge the support provided by the National Council on Science and Technology (CONACYT); LICAMM UG: Laboratory of research and characterization of minerals and materials, for providing access to XRF and XRD equipment and to the University of Guanajuato, México. We also thank the Michoacán University of San Nicolas of Hidalgo (UMSNH), Morelia, Michoacán, México, for providing access to SEM and TEM equipment facilities.
Conflict of interest. The authors declare that they have no conflict of interest.

\section{REFERENCES}

[1] J. A. Kaddissy, S. Esnouf, D. Saffré, J. P. Renault, Efficient hydrogen production from irradiated aluminum hydroxides, Int. J. Hydrogen. Energ., 44, 3737-3743 (2019). DOI: https://doi.org/10.1016/j.ijhydene.2018.12.089

[2] M. Sobhani, H. Tavakolia, M. D. Chermahini, M. Kazazi, Preparation of macro-mesoporous $\gamma$-alumina via biology gelatin assisted aqueous sol-gel process, Ceram. Int., 45, 1385-1391 (2019). DOI: https://doi.org/10.1016/j.ceramint.2018.09.056

[3] J. H. Roque Ruiz, N. A. Medellín Castillo, S. Y. Reyes López, Fabrication of $\alpha$-alumina fibers by sol-gel and electrospinning of aluminum nitrate precursor solutions, Results Phys., 12, 193-204 (2019).

DOI: https://doi.org/10.1016/j.rinp.2018.11.068

[4] Z. Yang, C. Qi, X. Zheng, J. Zheng, Synthesis of Ag/ $\gamma$ $\mathrm{AlOOH}$ nanocomposites and their application for electrochemical sensing, J. Electroanal. Chem., 754, 138142 (2015).

DOI: https://doi.org/10.1016/j.jelechem.2015.07.022

[5] F. Chen, F. Wang, Q. Li, C. Cao, X. Zhang, H. Ma, Y. Guo, Effect of support (Degussa P25 $\mathrm{TiO}_{2}$, anatase $\mathrm{TiO}_{2}, \gamma-\mathrm{Al}_{2} \mathrm{O}_{3}$, and $\mathrm{AlOOH}$ ) of Pt-based catalysts on the formaldehyde oxidation at room temperature, Catal. Commun., 99, 39-42 (2017).

DOI: https://doi.org/10.1016/j.catcom.2017.05.019

[6] H. Hou, Y. Zhu, G. Tang, Q. Hu, Lamellar $\gamma-\mathrm{AlOOH}$ architectures: Synthesis and application for the removal of HCN, Mater. Charact., 68, 33-41 (2012). DOI: https://doi.org/10.1016/j.matchar.2012.03.001 
[7] S. Roy, S. Bardhan, K. Pal, S. Ghosh, P. Mandal, S. Das, S. Das, Crystallinity mediated variation in optical and electrical properties of hydrothermally synthesized boehmite $(\gamma-\mathrm{AlOOH})$ nanoparticles, J. Alloy Compd., 763, 749-758 (2018).

DOI: https://doi.org/10.1016/j.jallcom.2018.05.356

[8] L. Liu, W. Huang, Z. Gao, L, Yin. Synthesis of AlOOH slurry catalyst and catalytic activity for methanol dehydration to dimethyl ether, J. Ind. Eng. Chem., 18, 123127 (2012)

DOI: https://doi.org/10.1016/j.jiec.2011.11.079

[9] H. Yanmei, G. Zhihua, H. Wei, Effects of $\mathrm{AlOOH}$ Structure on the Reaction of Methanol and Carbon Monoxide, Chem. J. Chinese U., 38, 823-829 (2017). DOI: http://www.cjcu.jlu.edu.cn/CN/10.7503/cjcu20160 862

[10] B. Bai, H. Bai, L. Zhang, W. Huang, Catalytic activity of $\gamma$-AlOOH (ll 001$)$ surface in syngas conversion: Probing into the mechanism of carbon chain growth, Appl. Surf. Sci., 455, 123-131 (2018).

DOI: https://doi.org/10.1016/j.apsusc.2018.05.174

[11] S. Nishimura, S. Ohmatsu, K. Ebitani, Selective synthesis of 3-methyl-2-cyclopentenone via intramolecular aldol condensation of 2,5-hexanedione with $\gamma$ $\mathrm{Al}_{2} \mathrm{O}_{3} / \mathrm{AlOOH}$ nanocomposite catalyst, Fuel Process. Technol., 196, 106185 (2019). DOI: https://doi.org/10.1016/j.fuproc.2019.106185

[12] G. Munusamy, K. Varadharajan, S. Narasimhan, U. G. Thangapandiyan, Investigation of $\gamma-\mathrm{AlOOH}$ and $\mathrm{NiWO}_{4}$-coated boehmite micro/nanostructure under UV/visible light photocatalysis, Res. Chem. Intermediat., 44, 1-20 (2018).

DOI: https://doi.org/10.1007/s11164-018-3588-5

[13] Z. Tang, J. Liang, X. Li, J. Li, H. Guo, Y. Liu, C. Liu, Synthesis of flower-like Boehmite $(\gamma-\mathrm{AlOOH})$ via a onestep ionic liquid-assisted hydrothermal route, J. Solid State Chem., 202, 305-314 (2013). DOI: https://doi.org/10.1016/j.jssc.2013.03.049

[14] X. Wu, D. Wang, Z. Hu, G. Gu, Synthesis of $\gamma-\mathrm{AlOOH}$ $\left(\gamma-\mathrm{Al}_{2} \mathrm{O}_{3}\right)$ self-encapsulated and hollow architectures, Mater. Chem. Phys., 109, 560-564 (2008). DOI: https://doi.org/10.1016/j.matchemphys.2008.01.004

[15] T. K. Vo, H. K. Park, C. W. Nam, S. D. Kimb, J. Kim, Facile synthesis and characterization of $\gamma-\mathrm{AlOOH} / \mathrm{PVA}$ composite granules for $\mathrm{Cr}(\mathrm{VI})$ adsorption, J. Ind. Eng. Chem., 60, 485-492 (2018).

DOI: https://doi.org/10.1016/j.jiec.2017.11.036

[16] S. O. Kazantsev, A. S. Lozhkomoev, E. A. Glazkova, I. Gotman, E. Y. Gutmanas, M. I. Lerner, S. G. Psakhie, Preparation of aluminum hydroxide and oxide nanostructures with controllable morphology by wet oxidation of AlN/Al nanoparticles, Mater. Res. Bull., 104, 97-103 (2018)

DOI: https://doi.org/10.1016/j.materresbull.2018.04.011

[17] X. Bokhimi, J. A. Toledo Antonio, M. L. Guzman Castillo, F. Hernandez Beltran, Relationship between crystallite size and bond lengths in boehmite, J. Solid State Chem., 159, 32-40 (2001).

DOI: https://doi.org/10.1006/jssc.2001.9124

[18] L. Yixuan, L. Chenxia, D. Degang, D. Bin, W. Le, X. Shiqing, Properties of boehmite $(\gamma-\mathrm{AlOOH})$ and $\mathrm{Eu}^{3+}$ doped boehmite synthesized by hydrothermal method, Optik, 154, 171-176 (2018).

DOI: https://doi.org/10.1016/j.ijleo.2017.09.093

[19] A. Wasti, M. A. Awan, Adsorption of textile dye onto modified immobilized activated alumina, J. Assoc. Arab U. Basic Appl. Sci., 20, 26-31 (2016).

DOI: https://doi.org/10.1016/j.jaubas.2014.10.001

[20] F. Karouia, M. Boualleg, M. Digne, P. Alphonse, Control of the textural properties of nanocrystalline boehmite $(\gamma-\mathrm{AlOOH})$ regarding its peptization ability, Powder Technol., 237, 602-609 (2013).

DOI: https://doi.org/10.1016/j.powtec.2012.12.054

[21] D. Panias, A. Krestou, Effect of synthesis parameters on precipitation of nanocrystalline boehmite from aluminate solutions, Powder Technol., 175, 163-173 (2007). DOI: https://doi.org/10.1016/j.powtec.2007.01.028

[22] R. Romero Toledo, V. Ruíz Santoyo, D. Moncada Sánchez, M. Martínez Rosales, Effect of aluminum precursor on physicochemical properties of $\mathrm{Al}_{2} \mathrm{O}_{3}$ by hydrolysis/precipitation method, Nova Sci., 20, 83-99 (2018). DOI: https://doi.org/10.21640/ns.v10i20.1217

[23] S. Sangita, N. Nayak, C. Ranjan Panda, Extraction of aluminium as aluminium sulphate from thermal power plant fly ashes, T. Nonferr. Metal Soc., 27, 2082-2089 (2017).

DOI: https://doi.org/10.1016/S1003-6326(17)60231-0

[24] K. Amin Matori, L. Chee Wah, M. Hashim, I. Ismail, M. H. Mohd Zaid, Phase transformations of $\alpha$-alumina made from waste aluminum via a precipitation technique, Int. J. Mol. Sci., 13, 16812-16821 (1996). DOI: $10.3390 /$ ijms131216812

[25] M. Yuan, X. Qiao, J. Yu, Phase equilibria of $\mathrm{AlCl}_{3}+$ $\mathrm{FeCl}_{3}+\mathrm{H}_{2} \mathrm{O}, \mathrm{AlCl}_{3}+\mathrm{CaCl}_{2}+\mathrm{H}_{2} \mathrm{O}$, and $\mathrm{FeCl}_{3}+\mathrm{CaCl}_{2}$ $+\mathrm{H}_{2} \mathrm{O}$ at $298.15 \mathrm{~K}$, J. Chem. Eng. Data, 61, 1749-1755 (2016). DOI: 10.1021/acs.jced.5b00932

[26] J. Shah, M. Rasul Jan, Adnan, Catalytic activity of aluminum impregnated catalysts for the degradation of waste polystyrene, Int. J. El. Commun. Eng., 8, 83-89 (2014). DOI: $10.5281 /$ zenodo. 2666243

[27] B. Pacewska, M. Keshr, Thermal transformations of aluminium nitrate hydrate, Thermochim. Acta, 385, 7380 (2002).

DOI: https://doi.org/10.1016/S0040-6031(01)00703-1

[28] E. Karimi Saeidabadi, T. Ebadzadeh, E. Salahi, Preparation of mullite from alumina/aluminum nitrate and kaolin clay through spark plasma sintering process, Ceram. Int., 44, 21053-21066 (2018). DOI: https://doi.org/10.1016/j.ceramint.2018.08.142

[29] C. Xueliang, Z. Yunfeng, T. Meng, D. Zhengping, Novel yolk-shell-structured $\mathrm{Fe}_{3} \mathrm{O}_{4} @ \gamma-\mathrm{AlOOH}$ nanocomposite modified with Pd nanoparticles as a recyclable catalyst with excellent catalytic activity, Appl. Surf. Sci., 416, 103-111 (2017).

DOI: https://doi.org/10.1016/j.apsusc.2017.04.048

[30] S. K. Sahoo, M. Tripathy, G. Hota, In-situ functionalization of GO sheets with $\mathrm{AlOOH}-\mathrm{FeOOH}$ composite nanorods: An eco-friendly nanoadsorbent for removal of toxic arsenate ions from water, J. Environ. Chem. Eng., 7, 103357 (2019).

DOI: https://doi.org/10.1016/j.jece.2019.103357 
[31] D. Mishra, S. Anand, R. K. Panda, R. P. Das, Effect of anions during hydrothermal preparation of boehmites, Mater. Lett., 53, 133-137 (2002).

DOI: https://doi.org/10.1016/S0167-577X(01)00461-X

[32] M. Abdollahifar, M. Hidaryan, P. Jafari, The role anions on the synthesis of $\mathrm{AlOOH}$ nanoparticles using simple solvothermal method, Bol. Soc. Esp. Ceram. V., 57, 66-72 (2018). DOI: https://doi.org/10.1016/j.bsecv.2017.06.002

[33] G. Wei, J. Qu, Y. Zheng, T. Qi, Q. Guo, B. Han, H. Zhao, Crystallization behaviors of bayerite from sodium chromate alkali solutions, T. Nonferr. Metal Soc., 24, 3356-3365 (2014). DOI: https://doi.org/10.1016/S1003-6326(14)63477-4

[34] W. Hernández Muñoz, J. Serrato Rodríguez, J. Muñoz Saldaña, J. Zárate Medina, Synthesis of lanthanum aluminate by reverse chemical precipitation using pseudoboehmite as alumina precursor, Appl. Radiat. Isotopes, 117, 96-99 (2016). DOI: https://doi.org/10.1016/j.apradiso.2016.01.026

[35] W. Tao, H. Zhong, X. Pan, P. Wang, H. Wang, L. Huang, Removal of fluoride from wastewater solution using $\mathrm{Ce}-\mathrm{AlOOH}$ with oxalic acid as modification, $J$. Hazard Mater. 384, 121373 (2020). DOI: https://doi.org/10.1016/j.jhazmat.2019.121373

[36] M. Milanović, Z. Obrenović, I. Stijepović, L. M. Nikolić, Nanocrystalline boehmite obtained at room temperature, Ceram. Int., 44, 12917-12920 (2018). DOI: https://doi.org/10.1016/j.ceramint.2018.04.103

[37] S. Li, H. He, Q. Tao, Y. Xi, A. Chen, S. Ji, C. Zhang, Y. Yang, J. Zhu, Transformation of boehmite into 2:1 type layered aluminosilicates with different layer charges un- der hydrothermal conditions, Appl. Clay Sci., 181, 105207 (2019).

DOI: https://doi.org/10.1016/j.clay.2019.105207

[38] L. H. Chagas, G. S. G. De Carvalho, R. A. S. San Gil, S. S. X. Chiaro, A. A. Leitao, R. Diniz, Obtaining aluminas from the thermal decomposition of their different precursors: An ${ }^{27} \mathrm{Al}$ MAS NMR and X-ray powder diffraction studies, Mater. Res. Bull., 49, 216-222 (2014). DOI: https://doi.org/10.1016/j.materresbull.2013.08.072

[39] W. Lueangchaichaweng, B. Singh, D. Mandelli, W. A. Carvalho, S. Fiorilli, P. P. Pescarmona, High surface area, nanostructured boehmite and alumina catalysts: Synthesis and application in the sustainable epoxidation of alkenes, Appl. Catal. A-Gen., 571, 180-187 (2019). DOI: https://doi.org/10.1016/j.apcata.2018.12.017

[40] F. Yang, Q. Wang, J. Yan, J. Fang, J. Zhao, W. Shen, Preparation of High Pore Volume Pseudoboehmite Doped with Transition Metal Ions through Direct Precipitation Method, J. Ind. Eng. Chem. Res., 51, 1538615392 (2012).

DOI: https://doi.org/10.1021/ie3017626

[41] N. Xu, Zhong Liu, S. Bian, Y. Dong, W. Li, Templatefree synthesis of mesoporous $\gamma$-alumina with tunable structural properties, Ceram. Int., 42, 4072-4079 (2016). DOI: https://doi.org/10.1016/j.ceramint.2015.11.079

[42] L. Yixuan, L. Chenxia, D. Degang, D. Binb, W. Le, X. Shiqing, Properties of boehmite $(\gamma-\mathrm{AlOOH})$ and $\mathrm{Eu}^{3+}$ doped boehmite synthesized by hydrothermal method, Optik, 154, 171-176 (2018).

DOI: https://doi.org/10.1016/j.ijleo.2017.09.093 
